\title{
Human Astrovirus and Cryptosporidium Co-infection among Children with Gastroenteritis in Diyala Governorate Amal I Naif $(\mathrm{BSc})^{1}$, Areej A Hussein $(\mathrm{PhD})^{2}$, Mohammed J Shaker $(\mathrm{MSc})^{3}$ and Rawaa A Hussein $(\mathrm{PhD})^{4}$ Abstract
}

Background: Gastroenteritis is the second leading cause of death in children under five years old. The highest mortality from diarrheal diseases in children lived crowded areas were poor sanitary and hygienic conditions found.

Objective: To determine the co-infections between human astrovirus and Cryptosporidium spp. among children with gastroenteritis below 5 years of age in the Diyala governorate.

Patients and Methods: A cross-sectional study was carried out for 100 patients with acute gastroenteritis who attended the Emergency Department of Pediatrics in Al-Batool Teaching Hospital for Maternity and Pediatric in Baqubah city, during the period from July 2019 to February 2020. Real time-PCR was used to detect human astrovirus while enzyme- linked immunosorbent assay was used to detect Cryptosporidium spp. A specific formula sheet was used to collect demographic data such as age, gender, mother education, and type of milk feeding.

Results: Out of 100 samples, 14 samples were positive for human astrovirus and 38 samples were positive for Cryptosporidium. The infection rate is more common in males (9 cases) (25cases) rather than females, and in age group less than years $11(78.58 \%)$ and $34(89.47 \%$ ) respectively. Artificial feeding showed higher frequencies of infection than others in the study population. Co-infection astrovirus and Cryptosporidium found in four patients, all of whom were males aged under one-year and the difference was statistically significant with all parameters.

Conclusion: A high proportion of positive cases for human astrovirus and Cryptosporidium spp. were notes in males and the age group less than one year's co-infection showed high frequency in the study population.

Keywords: Gastroenteritis, human astrovirus, Cryptosporidium, co-infection

Corresponding Author: Arej.2002@yahoo.com

Received: $27^{\text {th }}$ June 2020

Accepted: $19^{\text {th }}$ July 2020

DOI:https://doi.org/10.26505/DJM.19025440627

${ }^{1,2,3,4}$ Department of Microbiology - College of Medicine -University of Diyala - Diyala - Iraq. 


\section{Introduction}

Gastroenteritis is an inflammatory condition of the stomach and intestines as an infectious particle spread by close contact of persons, contaminated food or water, and infected surfaces or material [1]. Many microorganisms can cause gastroenteritis, such as bacteria, parasites, viruses, and fungus. However, viral gastroenteritis is regarded as most common one [2]. Human astrovirus (HAstV) virions are $28-35 \mathrm{~nm}$ in diameter, non-enveloped and icosahedral symmetry, Astroviruses are non-segmented single-stranded positive-sense RNA viruses, it is now divided into two genera Mamastrovirus (MAstV), including viruses infecting mammals, and genus Avastrovirus (AAstV), including viruses infecting avian species [3]. Transmission of HAstV by the fecal-oral route or as person to person contact [4]. The primary site of human astrovirus replication seems to be the gastrointestinal tract, disseminated diseases, and encephalitis have been associated with infection with classic and non-classic astroviruses [5].

Co-infection involves globally serious diseases is concentrated among the poor and is often associated with worse host health and higher infections abundance than hosts with single infection [6]. Cryptosporidium is the second major cause of moderate to severe diarrhea in children under five years, and an important cause of mortality worldwide after Rotavirus [7]. The human cryptosporidiosis is caused by infection with apicomplexan protozoans of the genus Cryptosporidium. Human illness was formerly thought to be caused by a single species, but molecular studies have demonstrated that it is caused by at least 15 different species [8]. Cryptosporidium is classified within the coccidian protozoan, direct and several indirect routes of transmission of Cryptosporidium have been identified [9].

In Iraq several studies have been carried out about co-infection; of these are Hussein et al., (2016) who studied cryptosporidiosis and co-infections with other parasites and rotavirus viral in Baghdad city [10], Hussein et al., (2018) who dealt with enteric virus coinfection with Giardia lamblia in Baqubah city, and the recent study of Harb et al., (2019) who focused on the relation between the bacterial, viral, and parasitic in stool specimens from children with acute diarrhea in Thi-Qar Governorate[11, 12]. So this study to determine the co-infections between human astrovirus sand Cryptosporidium spp. among children with gastroenteritis below 5 years of age in Diyala governorate.

\section{Patients and Methods}

A cross-sectional study was carried out for 100 patients with acute gastroenteritis who attended the Emergency Department of Pediatrics in Al-Batool Teaching Hospital for Maternity and Pediatric in Baqubah city, during the period from July 2019 to February 2020. Fresh stool samples were taken from 100 patients having acute diarrhea 56 were males and 44 were females under the age of five years old, are admitted during the study period.

\section{Viral RNA extraction}

Viral RNA was extracted from stool samples using viral RNA using the (QIAamp Viral RNA Mini Kit - Germany). 


\section{RT-PCR}

Using in RT-PCR kit AmpliSens® Astrovirus-FRT. The total reaction volume is $25 \mu 1$. The type of tubes depends on the type of PCR real-time instrument. Disposable filter tips were used for adding reagents, cDNA, and control samples into tubes. Reaction mixture: the components were mixed just before the analysis by calculating the required reaction number (including test and control samples). The reaction mixture consists of mix $10 \mu \mathrm{l}$ of RT-PCR-mix-1FEP/FRT

(RT-PCR-mix-1-FEP/FRT)

Astrovirus, $5 \mu 1$ of RT-PCR-mix-2 FEP/FRT, $0.5 \mu \mathrm{l}$ polymerase (TaqF), $0.25 \mu \mathrm{l}$ TMRevertase (MMlv) and 0.25RT-Gmix-2 according to kit instructions. Vortex the tubes thoroughly and make sure that there are no drops on the walls of the tubes. Then $15 \mu$ of the prepared mixture was mixed into the prepared tubes. Then $10 \mu$ of RNA was added to obtain at the RNA extraction stage to the prepared tubes using tips with aerosol filter. Finally, the control amplification reactions were carrying out.

NCA / $10 \mu$ l of DNA-buffer was added to the tube labeled NCA (Negative Control of Amplification).

C+Astrovirus $/ 10 \mu \mathrm{l}$ of Positive Control cDNA Astrovirus (C+ Astrovirus) was added (in case of using RT-PCR-mix-1-FEP/FRT Astrovirus) to the tube labeled Astrovirus (Positive Control of Amplification).

C-Astrovirus $/ 10 \mu$ l of the sample extracted from the Negative Control (C-)reagent was added to the tube labeled $\mathrm{C}-$ (Negative control of Extraction).

Create a temperature profile on Amplification program was done by Rotortype instruments as follows: Fluorescent signal is detected in the channels for the FAM and JOE fluorophores, the fluorescence channel sensitivity was regulated then tubes were inserted into the reaction module of the device finally run the amplification program with fluorescence detection and Analyze results after the amplification program.

Table (1): Thermal program for RT-PCR

\begin{tabular}{|c|c|c|c|}
\hline Step & Temperature, ${ }^{\circ} \mathrm{C}$ & Time & Repeats \\
\hline 1 & 50 & $30 \mathrm{~min}$ & 1 \\
\hline 2 & 95 & $15 \mathrm{~min}$ & 1 \\
\hline 3 & $\begin{array}{l}95 \\
60 \\
72 \\
\end{array}$ & $\begin{array}{c}10 \mathrm{~s} \\
25 \mathrm{~s} \text { fluorescent signal detection } \\
10 \mathrm{~s} \\
\end{array}$ & 45 \\
\hline
\end{tabular}

\section{Enzyme- linked immune sorbent assay}

Sandwich enzyme-linked immune sorbent assay by using RIDASCREEN Cryptosporidium $3^{\text {rd }}$ generation (Cat No. C1201- Germany) according to manufacturing instruction.

\section{Statistical analysis}

All data were analyzed using the statistical package for social sciences (SPSS), version 22. A Chi-square test was used to find out the effect of different patients' criteria on the reading of each test. 


\section{Results}

The rate of human astrovirus infection was $14 \%$ (14 out of 100) samples tested using real-time polymerase chain reaction among children under five years old. The rate of human astrovirus infection among males $9(64.29 \%)$ was higher than females $5(35.71 \%)$ and statistically significant. The age of patient ranged from 1month to 60 months, the positive result $11(78.57 \%)$ was in the age group 1-12 month and 3 (21.43\%) their age was 13-24months, while no positive cases among other age groups, statistical analysis showed highly significant differences as shown in Figure (1) and Table (2).

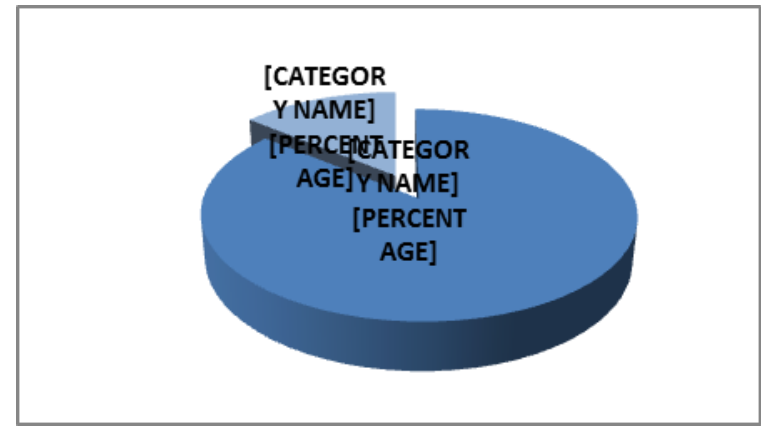

Figure (1): Infection rate of human astrovirus using real time polymerase chain reaction technique

Table (2): Distribution of human Astrovirus according to their age and gender

\begin{tabular}{|c|c|c|c|c|}
\hline \multicolumn{2}{|c|}{ Variable factors } & \multirow{2}{*}{$\begin{array}{c}\begin{array}{c}\text { Study } \\
\text { population } \\
\text { No. }(\%)\end{array} \\
55\end{array}$} & \multirow{2}{*}{$\begin{array}{l}\text { Positive } \\
\text { No. (\%) } \\
9(64.29) \\
\end{array}$} & \multirow{3}{*}{$\begin{array}{c}\text { P-value } \\
8.538 * * \\
(0.0067)\end{array}$} \\
\hline \multirow{2}{*}{ Gender } & Males & & & \\
\hline & Females & $\begin{array}{l}45 \\
\end{array}$ & $\begin{array}{l}5(35.71) \\
\end{array}$ & \\
\hline \multirow{4}{*}{$\begin{array}{l}\text { Age group } \\
\text { (month) }\end{array}$} & $1-12$ & 90 & $111(78.57)$ & \multirow{5}{*}{$\begin{array}{c}12.641 \text { ** } \\
(0.0001)\end{array}$} \\
\hline & 13-24 & 6 & $3(21.43)$ & \\
\hline & $25-36$ & 3 & 0 & \\
\hline & $37-48$ & 1 & 0 & \\
\hline Total & & 100 & $14(100)$ & \\
\hline
\end{tabular}

** $(\mathrm{P} \leq 0.01)$-Higly significant.

Patients with gastroenteritis were divided into three groups according to the various types of feeding, the highest infection rate of human astrovirus was noticed in patients who used artificial feeding 13(92.86\%) followed by breastfeeding 1(7.14\%), while there were no positive cases in children with mixed feeding. However, the statistical analysis did not yield any significant differences among these groups as shown in Table (3). 
Table (3): Distribution of human astrovirus results according to type of feeding

\begin{tabular}{|l||c||c||c||c||}
\hline \hline Type of feeding & $\begin{array}{c}\text { Total } \\
\text { No. }\end{array}$ & $\begin{array}{c}\text { Positive } \\
\text { No. }(\mathbf{\%})\end{array}$ & $\begin{array}{c}\text { Negative No. } \\
(\mathbf{\%})\end{array}$ & P-value \\
\hline \hline Breast feeding & 8 & $1(7.14)$ & $7(8.14)$ & $14.619^{* *}$ \\
\hline \hline Artificial feeding & 74 & $13(92.86)$ & $61(70.93)$ & \multirow{2}{*}{$(0.0001)$} \\
\hline Mixed feeding & 14 & 0 & $14(16.28)$ & \\
\hline Tablet & 4 & 0 & $4(4.65)$ & \\
\cline { 1 - 3 } Total & 100 & $14(100)$ & $86(100)$ & \\
\hline
\end{tabular}

** $(\mathrm{P} \leq 0.01)$-Hghly significant.

One hundred patient with diarrhea was examined by enzyme-linked immunosorbent assay to detect Cryptosporidium spp. and the result of the present study was demonstrated that $38 \%$ of stool samples were positive for Cryptosporidium spp, The infection rate of Cryptosporidium spp. was more common in males $25(65.79 \%)$ than females $13(34.21 \%)$. The highest infection rates $(89.47 \%)$ were noticed in age group (1-12 months) followed by $3(7.90 \%)$ within the age group (13-24 months). The statistical analysis showed highly significant differences among gender and age as shown in Figure (2) and Table (4).

\section{Infection Rate of Cryptosporidium spp.}

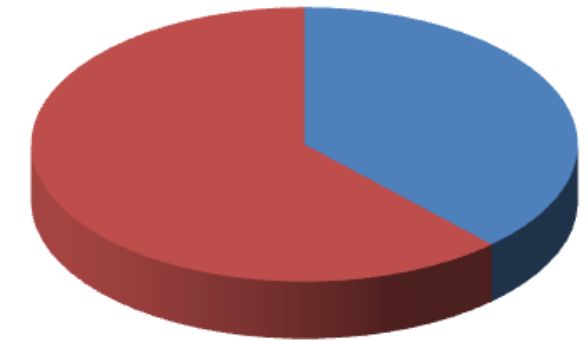

\section{Positive results Negative results}

Figure (2): Infection rate of Cryptosporidium spp. using ELISA technique

Table (4): Distribution of Cryptosporidium spp. according to age, gender

\begin{tabular}{|c|c|c|c|c|c|}
\hline \multicolumn{2}{|c|}{ Variable factors } & $\begin{array}{l}\text { Total } \\
\text { No. }\end{array}$ & $\begin{array}{l}\text { Positive } \\
\text { No. }(\%)\end{array}$ & $\begin{array}{l}\text { Negative } \\
\text { No. }(\%)\end{array}$ & P-value \\
\hline \multirow{2}{*}{ Gender } & $\begin{array}{l}\text { Males } \\
\end{array}$ & 255 & $25(65.79)$ & 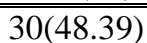 & \multirow{2}{*}{$\begin{array}{l}8.704 * * \\
(0.0069)\end{array}$} \\
\hline & Females & $\overline{45}$ & $13(34.21)$ & $32(51.61)$ & \\
\hline \multirow{4}{*}{$\begin{array}{l}\text { Age group } \\
\text { (months) }\end{array}$} & " & $\overline{990}$ & $34(89.47)$ & 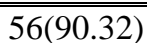 & \multirow{5}{*}{$\begin{array}{r}13.569 * * \\
(0.0001)\end{array}$} \\
\hline & $\overline{13-24}$ & 6 & $3(7.89)$ & $3(4.84)$ & \\
\hline & $25-36$ & 3 & $21(2.63)$ & $2(3.23)$ & \\
\hline & $37-48$ & $\overline{11}$ & 0 & $1(1.61)$ & \\
\hline Total & & 100 & $38(100)$ & $62(100)$ & \\
\hline
\end{tabular}

** $(\mathrm{P} \leq 0.01)$ - Highly significant.

Distribution of Cryptosporidium spp. patients who used artificial feeding infection, according to different sources of 29(76.31\%) followed by mixed feeding feeding types were shown in Table 5. The $8(21.06 \%)$ and the differences were highest infection rate was noticed among statistically significant at $\mathrm{P} \leq 0.01$. 
Table (5): Distribution of positive Cryptosporidium spp. cases according to feeding type

\begin{tabular}{|c|c|c|c|c|}
\hline Type of feeding & $\begin{array}{c}\text { Total } \\
\text { No. }(\%)\end{array}$ & $\begin{array}{l}\text { Positive } \\
\text { No. }(\%)\end{array}$ & $\begin{array}{l}\text { Negative } \\
\text { No. }(\%)\end{array}$ & P-value \\
\hline Breast feeding & 8 & $1(2.63)$ & $7(11.30)$ & \multirow{4}{*}{$\begin{array}{l}12.683 \\
* * \\
(0.0001)\end{array}$} \\
\hline Artificial feeding & 74 & $29(76.31)$ & 4 45(72.58) & \\
\hline Mixed feeding & 18 & $8(21.06)$ & $10(16.12)$ & \\
\hline Total & 100 & $38(100)$ & 62(100) & \\
\hline
\end{tabular}

Regarding co-infection between human astrovirus and Cryptosporidium spp, 4 cases showed co-infection between two pathogens, all of them were from males and in age

Table (6): Distribution human astrovirus and Cryptosporidium spp. co-infection according to demographic characteristics

\begin{tabular}{|c|c|c|c|}
\hline Characteristics & $\begin{array}{l}\text { Total Number of } \\
\text { children }\end{array}$ & $\begin{array}{c}\text { Human Astrovirus } \\
\text { and Cryptosporidium } \\
\text { Positive No. }(\%)\end{array}$ & $\begin{array}{c}\text { Chi-Square }-\chi 2 \text { : } \\
\text { (P-value) }\end{array}$ \\
\hline \multirow[t]{2}{*}{ Gender } & Male & $4(100)$ & \multirow{2}{*}{$\begin{array}{l}15.00 * * \\
(0.0001)\end{array}$} \\
\hline & Female & 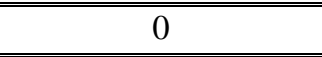 & \\
\hline \multirow[t]{4}{*}{ Age } & 1-12 month & 4 (100) & \multirow{4}{*}{$\begin{array}{l}15.00 * * \\
(0.0001)\end{array}$} \\
\hline & 13-24 month & 0 & \\
\hline & 25-36 month & 0 & \\
\hline & 37-48month & 0 & \\
\hline \multirow{4}{*}{$\begin{array}{l}\text { Mother } \\
\text { educational } \\
\text { level }\end{array}$} & Illiterates & $4(100 \%)$ & \multirow{4}{*}{$\begin{array}{l}15.00 * * \\
(0.0001)\end{array}$} \\
\hline & Primary education & $0(0 \%)$ & \\
\hline & Secondary education & $0(0 \%)$ & \\
\hline & High education & $0(0 \%)$ & \\
\hline
\end{tabular}

\section{Discussion}

The current study found out that the infection rate of human astrovirus was $14 \%$ depending on the real-time polymerase chain reaction result of stool samples from children with gastroenteritis who were admitted to AlBatool Teaching Hospital for maternity and children in the Diyala governorate. This result was similar to the result of Zaki and ElKheir (2017) who reported $14 \%$ by multiplex reverse transcriptase-polymerase chain reaction in Egyptian children below five years old with diarrhea [13]. Furthermore, the result is comparable with several studies that group (1-24) months as well as with illiterate mother in terms of their educational level, as shown in Table (6). 
infection with Bocavirus of Infantile in Egypt [16]. On the other hand, the result of this study is high compared with the data reported by Iraqi researchers; such as Hussein et al., (2018) who did not record any positive cases among children with diarrhea in Diyala province [11] and Thewiny et al., (2014) who reported $2.6 \%$ of human astrovirus among hospitalized children under five years old in Basrah city [17]. These differences could be attributed to the fact that, the virus varies from one region to another and from year to year due to diversity in the study which excelled it. These can cause age layer's effectiveness of variance in drugs, their effects, the sampling season as well as the type of adopted technique and sample size.

In terms of gender, it has been found that human astrovirus infection in males $9(64.29 \%)$ was more than in females $5(35.71 \%)$ and the difference was statistically significant. This result seems to be similar to those conducted in other Iraqi studies such as Thewiny et al., (2014) in Basra [17], and AlSadawi et al., (2017) in Najaf [18]. These indicate that infection rates in males are more than in females because of the environmental condition, immune status, nutrition and which are mixed compared to females who are more mobile and integrated with the surrounding environment that may be contaminated with pathogens.

Regarding the age of patients, it has been found that human astrovirus infection rates were high 11(78.58\%) in the age group (1-12 months) when compared to other age groups, yet still, such differences were statistically significant. This result was comparable with the results of many Iraqi studies like Al-
Sadawi et al., (2017) in Najaf [18] and Fadhil et al., (2020) in Baghdad [15]. This is due to the notion that viruses tend to spread to the hands that have touched the stools of the infected person or surfaces contaminated with infected stools, especially parents who prepare meals in bows with their hands without commitment to personal hygiene.

According to the type of feeding, artificial feeding has the highest frequency of 13 (92.86\%) among other types of feeding and the difference was statistically significant. This result is in harmony with other Iraqi studies such as, Harb et al., (2019) in Thi-Qar Governorate [12], and Tuky et al., (2019) in Karbala [19]. Breast milk is the ideal food for infants. It is safe, clean, and contains antibodies that help protect against many common childhood illnesses. Breast milk provides all the energy and nutrients that the infant needs for the first months of life, and it continues to provide up to half or more of a child's nutritional needs during the second half of the first year, and up to one third during the second year of life (WHO, 2019)[20].

The infection rate of Cryptosporidium spp, was (38\%) using ELISA technique. This percentage was comparable with many studies conducted in different Iraqi cites; such as Rahi et al., 2013 who reported 33.83 $\%$ among children by modified Ziehl-Neelsen acid-fast stain and ELISA in Wasit Province [21], Al-Difaie (2015) who recorded (39.2\%) using conventional PCR technique in AlQadisiya Governorate [22]. The infection rate of Cryptosporidium in this study is relatively low if compared with the data reported by Rahi and Raheem (2013) who reported (50\%) 
among children in Wasit Province [23], Sayal (2019) who recorded an infection rate of $58 \%$ in Najaf [24]. The rate of Cryptosporidium infection in this study was high if compared to the data reported by Obiad et al., (2019) who recorded $0.98 \%$ in Kirkuk [25], AlKhuzaey and Al-Aboody, (2019) who reported $(19.8 \%)$ as infection rate in Thi-Qar [26], Al-Mounasi, (2018) who recorded 23.8\% in Basra [27], Mohammed et al., (2016) who stated 24\% in Al-Qadisiya [28] .In general, the difference in the rates of Cryptosporidium spp. infection between this study and other studies can be explained on the basis of similarity and difference in the different climatic conditions of the site, variations in the nutritional status, immunity of the patient, health habits, health supplies, socioeconomic status as well as the type of techniques adopted in the detection and sample size.

As for gender distribution, it has been found that Cryptosporidium infection in males with a rate of $25(65.79 \%)$ was more than in females $13(34.21 \%)$ and the difference was statistically significant. This result is similar to those found out in other studies; such as Ali (2013) in Sulaymaniyah [29], Al-Kubaisy (2015) in Baghdad [30], and Salman et al., (2015) in Kirkuk [31].

Regarding the age, it has been found that Cryptosporidium spp. infection rates were high $34(89.47 \%)$ in the age group less than one year. This result was in agreement with the studies of Rahi et al., (2013) in the Kut [32], and Saleh et al., (2017) in Erbil [33]. Children at this age do not realize the things that may be contaminated and play with anything without realizing that it may be contaminated with oocyst. It is also difficult to control their behavior all the time in addition to the contamination of bottles of milk in artificial feeding as well as crawling on a land packed with pollutants.

The type of feeding was considered in the current study. So, basically, the positive outcome of the Cryptosporidium spp. was higher in patients who used artificial feeding $29(76.31 \%)$ than others and the difference was statistically significant. This study agreed with the studies of Rahi and Raheem (2013) in the Kut [23] and Tuky et al., (2019) in Karbala [19]. This feeding type is a fertile ground for transporting cyst in a very easy way. It is the most dangerous factor of cryptosporidiosis in children if it is prepared by an infected person, which facilitates transmission. This explains the importance of breastfeeding because it is safe, clean, nutritious, and provides protection from infections because it strengthens the immune system and gives antibodies against infection. The results of the present study showed that 4 cases had co-infection between astrovirus and Cryptosporidium that detected in males and children less than one year old. The study is comparable to the studies of Pativada et al, (2012) who reported that 5 cases had coinfection between human astrovirus and Cryptosporidium among infants, children and adults hospitalized with acute watery diarrhea in India [34]. According to gender distribution, the results of this study agreed with the study done by Hawash et al., (2017) in Korea [35], while they disagreed with Anna et al., (2019) in Laos [36]. It reported that females are more subject to infection than male's co-infection enteric virus and 
Cryptosporidium spp., due to an increased level of immunity which can be beneficial in protecting against and removing a proportion of pathogens.

Regarding to age Pediatr et al., (2019) showed that the co-infection between Astrovirus and other enter viruses is most common under 2 years [37], while Mozhgani et al., (2012) in Iran [38], Vu et al., (2020) in Spain, proved that the vast majority of children had co-infection with human astrovirus while they were one year old and under [39 ]. This may be related to the reality that in the lower age groups, infection of human astrovirus, and Cryptosporidium spp. Therefore, according to this study, the rate of co-infections of human astrovirus and Cryptosporidium spp. were considered in some certain areas, due to the fact that prevention methods for both are similar. Improvements in sanitation, especially hand washing, and vaccinations for astrovirus will reduce the infections with this virus. Coinfection co-incidence with this virus appears in cases of contamination of food and drinking water in this region. So, improvements in sanitation and vaccinations may reduce the incidence of this virus.

\section{Conclusions}

In conclusions, high proportion of positive cases for human astrovirus and Cryptosporidium spp. were notes in males and age group less than one year's co infection showed high frequency in study population.

\section{References}

[1]Shane AL, Mody RK, Crump JA, Tarr PI, Steiner TS, Kotloff K, Langley JM, Wanke C, Warren CA, Cheng AC, Canteym J,
Pickering LK. Infectious Diseases Society of America Clinical Practice Guidelines for the Diagnosis and Management of Infectious Diarrhea. Clin Infect Dis, 2017; 65(12):19631973.

[2]Kolsin JM, Lopman BA, Payne DC, Wikswo ME, Dunn JR, Halasa NB, Hall A J. Evaluating previous antibiotic use as a risk factor for acute gastroenteritis among children in Davidson county, Tennessee, 2014-2015. J Pediatric Infect Dis Soc. 2018; 7(3): e86-e91.

[3]Cortez V, Meliopoulos V, Karlsson E, Hargest V, Johnson C, Cherry S. Astrovirus biology and pathogenesis. Annu Rev Viral. 2017; 4(1):327-348.

[4]Jacob-Macdonald AA, Halley S, Chander D, Gunson R, Shepherd SJ, Parcell BJ. First report of an astrovirus type 5 gastroenteritis outbreakin residential elderly Care home identified by sequencing. J Clin Viral; 2015; 73:115-119.

[5]Giannitti F, Caffarena RD, Pesavento P, Uzal FA, Maya L, Fraga M, Colina R, Castells M. The first case of bovine astrovirus associated encephalitis in the southern hemisphere (Uruguay) uncovers evidence of viral introduction to the Americas from Europe. Front Microbiol. 2019; 10 (12): 40.

[6]Bakaletz LO. Viral-bacterial co-infections in the respiratory tract. Curr Opin Microbiol. 2017; 35: 30-35.

[7]Bones AJ, Jossé L, More C, Miller CN, Michaelis M, Tsaousis AD. Past and future trends of Cryptosporidium in vitro research. Exp Parasitol, 2019; 196:28-37.

[8]White AC, Bennett JE, Dolin R, Blaser MK. Principles and practice of infectious 
disease. Philadelphia, Elsevier Inc. 2020; 3410-3420.

[9]Chalmers RM, Robinson G, Elwin K. Analysis of the Cryptosporidium spp. and gp60 subtypes linked to human outbreaks of cryptosporidiosis in England and Wales, 2009 to 2017. Parasite \&Vector. 2019; 12: 95 [10] 10- Hussein RA, Nada MA, Areej AM. Evaluation of multiplex real-time and ELISA in detection of intestinal protozoan parasites and co-infection with rotavirus from children with diarrheal disease, Ph.D., Thesis, AlNahrain University - College of Medicine 2016., Iraq.

[11]Hussein AA, Rawaa AH, Mouhammed J Sh. Enteric viruses' co-infection with giardiasis among diarrheal children in Diyala Province-Iraq. J Pu Appl Microbiol. 2018; 12(2): 793-799.

[12]Harb A, Abraham S, Rusdi B, Laird T, O'Dea M, Habib I. Molecular detection and epidemiological features of selected bacterial, viral, and parasitic enteropathogens in stool specimens from children with acute diarrhea in Thi-Qar Governorate, Iraq. JESPH. 2019;16: 1573.

[13]Zaki ME, El-Kheir NA. Molecular study of astrovirus, adenovirus and norovirus in community acquired diarrhea in children: One Egyptian center study. Asian Pac J Trop Biomed. 2017; 7(11) 987-90.

[14]Al-Shuwaikh AMA. Frequency of rotavirus, adenovirus and astrovirus among patients with acute diarrhea by chromatographic immunoassay and enzyme linked immunosorbent assay. J Biotech Res Center. 2016; 10(2): 58-64.

[15]Fadhil HY, Abed-Al-kareim MJ, Aufi IM, Al-Hamdani FG. Molecular detection of astrovirus using reverse transcriptase quantitative polymerase chain reaction technique. TIJAS. 2020; 51(Special Issue):191-200.

[16]El-Mosallamy WA, Awadallah MG, Abd El-Fattah MD. Human bocavirus among viral causes of infantile gastroenteritis. Egypt $\mathbf{J}$ Med Microbiol. 2015; 24 (3):12.

[17]Thewiny HT, Hasony HJ, Salman BD. Human astrovirus among hospitalized children under five years of age with acute diarrhea in Basrah, Iraq. Med J B Uni. 2014; 32(2): 71-76.

[18]Al-Sadawi AA, Ammar M, Tuwaij NS. Viral agent that causing diarrhoea among children in Al-Najaf province, Iraq. World $\mathbf{J}$ Pharma Res. 2017; 6(8): 1-11.

[19]Tuky HS, Semender BA. Assessing risk factors and causative organisms of acute diarrhea in children under 5 years in AlHindiya, Karbala, Iraq. Med $\mathrm{J}$ Babylon. 2019; 16:357-61.

[20]World Health Organizaiton. (2019). https://www.who.int/health-

topics/breastfeeding.

[21]Rahi AA, Ali MA, Charrakh AH. Prevalence of Cryptosporidium parvum among children in Iraq. Am J Life Sci. 2013; 1(6): 256-260.

[22]Al-Difaie RSS. Identification of Cryptosporidium parvum parasite oocyst using microscopic and PCR assay for detection GP900gene, QJPS, 2015 ., 3 (20): 28-40.

[23]Rahi AA, Rahem HH. Prevalence of Cryptosporidium parvum among children at Waist Province. J Was Sci Med. 2013; 6(1): 105-111. 
[24]Sayal RA. Epidemiological Study of Cryptosporidium Infection in Al-Najaf City. Int J Pharm Qual Assur. 2019; 10(01): 128131.

[25]Obiad HM, Aloosi T, Jboori AH, Obaid H. An epidemiologic study on Cryptosporidium spp. in Kirkuk city with some trials for in vitro treating the parasite. Sci Conf.2019; 8 (1):86-95.

[26]Alkhuzaey A, Aboody B. Co-infection of intestinal parasites and Helicobacter pylori in Patients with Chronic Diarrhea in Some Districts of Thi-Qar province. Iraqi J Biotech. 2019; 18(2): 18-27.

[27]Al-Mounasi MS. Epidemiological study on Cryptosporidium among children in Basra Province-Iraq. J Phys Conf Ser. 2018; 1032 012072.

[28]Mohammed NQ, Abd AH, Ahmad HS. Detection of Cryptosporidium parvum from feces samples of human and camels by using direct Polymerase Chain Reaction assay technique. QJVMS. 2016; 15 (2): 59-62.

[29]Ali FM. Cryptosporidiosis in Sulaimani Pediatric Teaching Hospital and comparison of different diagnostic methods for its detection. M.Sc. Thesis. Eur Sci J. 2013; 9(36): 454-464.

[30]Al-Kubaisy W, Badre A, Naggar RA, Shamsidah NI. pidemiological study of bloody diarrhoea among children in Baghdad Iraq. Int Arch Med. 2015; 8:1-9.

[31]Salman Y, Wajdi S, Khorsheed RZ. Original research article prevalence of Cryptosporidium parvum among Iraqi displaced people in Kirkuk city using direct microscopy, flotation technique and ELISAcopro antigen test. App Sci. 2015; 4(11): 559-572.
[32]Rahi AA. Comparison among modified acid-Fast stain and some Immunological methods in diagnosis of Cryptosporidium parvum in Kut City. J Was Sci Med. 2013; 6 (1): 12-20.

[33]Saleh K, Hawezy A, Majeed P. Prevalence of Cryptosporidium spp. among hospitalized children with diarrhea using ELISA and conventional microscopic techniques, in Erbil province. Polytechnic. J. 2017; 7(3): 1-11.

[34]Pativada, M., Nataraju, S.M., Ganesh, B., Rajendran, K., Ramamurthy, T., Ganguly, S., Bhattacharya, M.K., Ghosh, M., Kobayashi, N., Krishnan, T. Emerging trends in the epidemiology of human astrovirus infection among infants, children and adults hospitalized with acute watery diarrhea in Kolkata, India. Infect Genet Evo. 2012; 12(8):1685-93.

[35]Hawash YA, Ismail KA, Almehmadi M. High frequency of enteric protozoan, viral, and bacterial potential pathogens in community-acquired acute diarrheal episodes: Evidence based on results of luminex gastrointestinal pathogen panel assay. Korean J Parasitol, 2017; 55(5): 513521.

[36]Anna NC, Baker KK, Tsai K , Levy K, Sistrunk JR, Chang H H, Freeman MC. Associations between soil-transmitted helminthiasis and viral, bacterial, and protozoal enteroinfections: a cross-sectional study in rural Laos. Parasites \& Vectors. 2019; 12: 216.

[37]Pediatr M, Aktaş O, Aydin H, Timurkan MO. A molecular study on the prevalence and coinfections of rotavirus, norovirus, astrovirus and adenovirus in children with 
gastroenteritis. Edizioni Minerva Medica. 2019; 71(5):431-437.

[38]Mozhgani SH, Faghihloo E, Makvandi M, Samarbasf-Zadeh AR. Phylogenetic analysis of human astrovirus infection among children suffering from gastroenteritis referred to aboozar hospital, Ahvaz, Iran. Iran J Virol. 2012; 6(3): 32-35.

[39] Vu D, Sabrià A, Aregall N, Michl K, Sabrià J, Garrido VR, Goterris L, Bosch A, Pintó RM, Guix S. A Spanish case-control study in <5-year-old children reveals the lack of association between MLB and VA astrovirus and diarrhea. Sci Rep. 2020; 10: 1760. 